\title{
A Rapid Test for Detection of Tribenuron-Methyl Resistance in Sunflower
}

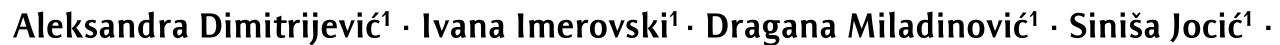 \\ Sandra Cvejić ${ }^{*}$ Goran Malidža' ${ }^{1}$ Branislav Kovačević ${ }^{2} \cdot$ Gordana Šurlan-Momirović ${ }^{3}$ \\ ${ }^{1}$ Institute of Field and Vegetable Crops, Maksima Gorkog 30, 21000 Novi Sad, Serbia \\ 2University of Novi Sad, Institute of Lowland Forestry and Environment, Antona Čehova 13, 21000 Novi Sad, Serbia \\ ${ }^{3}$ University of Belgrade, Faculty of Agriculture, Nemanjina 6, 11080 Zemun, Serbia
}

\begin{abstract}
Summary: A rapid laboratory test for detection of tribenuron-methyl resistant sunflower genotypes was developed. Four homozygous and four heterozygous tribenuron-methyl resistant hybrids, as well as a susceptible one were grown on MS medium supplemented with different concentrations of herbicide $(2.0 \mu \mathrm{M}, 2.5 \mu \mathrm{M}, 3.0 \mu \mathrm{M}, 3.5 \mu \mathrm{M}$ and 4.0 $\mu \mathrm{M})$ and with $\mathrm{pH}$ either 7 or 8 . The effect of medium $\mathrm{pH}$ and herbicide concentration on above-ground part and root mass of sunflower seedlings was observed. The test enabled visual discrimination between resistant and susceptible genotypes in 5 days, and discrimination between homozygous and heterozygous resistant genotypes in 12 days. All tested herbicide concentrations and morphological parameters were found to be suitable for discrimination of tribenuron-methyl susceptible genotypes. The best $\mathrm{pH}$ and herbicide concentration combination and morphological parameter for discrimination between homozygous and heterozygous resistant sunflower genotypes were $3.0 \mu \mathrm{M}$ at $\mathrm{pH} 7$ and root mass, respectively.

Key words: bioassay, Helianthus annuus L., herbicides, selection, sulfonylureas, tolerance
\end{abstract}

\section{Introduction}

Weeds could significantly reduce sunflower (Helianthus annuus L.) yield. This reduction could range between $20 \%$ and $53 \%$ in comparison to weed-free conditions (Blamey \& Zollinger 1997). Even though sunflower is an important oil crop worldwide, there are no herbicides for post-emergence weed control. Existing soil herbicides are often ineffective in suppression of small-seeded weed species and largeseeded broad-leaved weeds, especially in years with rainfall deficits occurring after herbicide application (Malidža et al. 2004). Therefore, introduction of AHAS inhibitors, sulfonylureas (SUs) and imidasolinones (IMIs), for weed control further facilitated sunflower production (Jocić et al. 2011).

Herbicides which inhibit activity of enzyme acetohydroxyacid synthase (AHAS, EC2.2.1.6, also known as acetolactate synthase ALS; EC 4.1.3.18) have proved to be useful in weed control, not just in sunflower, but in a number of crops such as tomato,

Corresponding author:

dragana.miladinovic@ifvcns.ns.ac.rs

Acknowledgements:

This work was supported by the Ministry of Education, Science and Technological Development, Republic of Serbia, project TR31025. The authors would like to thank Zvonimir Sakač, MSc for technical assistance in the preparation of manuscript. potato, maize, rapeseed, etc. Inhibition of activity of AHAS leads to inhibition of synthesis of three essential, branched-chain amino acids: valine, leucine and isoleucine, which causes inhibition of cell division and eventually cell death (Umbarger 1978, LaRossa \& Schloss 1984). There are several groups of AHAS inhibitors: sulfonylureas (SUs), imidazolinones (IMIs), triazolopyrimidines (TPs), pyrimidinylthiobenzoates (PTBs) and sulfonylaminocarbonyltriazolinone (SCTs) (Menne \& Kocher 2007). Tribenuron-methyl (TBM) is a member of sulfonylurea family of AHAS-inhibiting herbicides. Advantages of use of SUs are relatively low amount of herbicide used for weed control (between 1.8 and $60 \mathrm{~g}$ a.i. ha $\mathrm{h}^{-1}$ ), low toxicity level on animals (Chipman et al. 1998, Janjić 2002) and short persistence in the soil, since they can be hydrolysed and microbially degraded in soil (Janjić 2002).

Al-Khatib et al. (1999) were first to report a tribenuron-methyl (TBM) resistant sunflower genotype. Resistance was discovered in wild $H$. annuus population. These populations were used to develop the first registered SU resistant sunflower genetic stocks: female genetic stock (oilseed maintainer) SURES-1 (Reg. no. GS-28, PI 633749) and restorer genetic stock SURES-2 (Reg. no. GS-29, PI 633750) (Miller \& Al-Khatib 2004). Jocić et al. (2008) found that resistance to TBM in cultivated sunflower is controlled by one dominant gene. As development of herbicide resistant crops has become important in modern breeding, the need for 
development of quick and reliable tests for identification of herbicide resistant genotypes increased. For shortening the long period of backcrossing it is important to develop tests that can enable discrimination between homozygous and heterozygous resistant genotypes. Advantages of the use of laboratory tests are that they do not depend on the environment and could be used for screening of a large number of plants in a short period of time (Vasić et al. 2002, Dimitrijević et al. 2012). Different types of laboratory tests were developed for SU resistance detection in cultivated crop and weedy species. Saunders et al. (1992) used an in vitro test to detect chlorsulfuron resistance in sugar beet (Beta vulgaris L.) through somatic cell selection. Zygotic embryo culture was used to test resistance of several wheat (Triticum aestivum L.) genotypes to different SU herbicides (Kondić-Špika \& Jevtić 2002, Kondić-Špika et al. 2009). Cirujeda et al. (2001) used a Petri dish-based assay for detection of TBM resistant Papaver rhoeas L. genotypes. In sunflower, in vitro ALS activity was used to discriminate between TBM resistant and susceptible genotypes (Božić et al. 2012). So far, in sunflower soilless and in vitro tests were developed only for IMI resistance testing (Vega et al. 2009, Breccia et al. 2011).

Up to our knowledge, there are no reports on a laboratory test for TBM resistance in sunflower. The aim of this work was to develop a quick, reliable and cheap laboratory test for TBM resistance screening of a large number of sunflower genotypes that would accelerate breeding for herbicide resistance and conversion of sunflower inbred lines into herbicide resistant form. The specific objectives of the study were to determine (i) the optimal combination between $\mathrm{pH}$ and herbicide concentration for discrimination between resistant and susceptible sunflower genotypes, as well as between homozygous and heterozygous resistant ones and (ii) most useful morphological parameter indicating TBM resistance/susceptibility.

\section{Materials and Methods}

\section{Plant material}

Four homozygous (HoF, HoT, HoP, HoM), and four heterozygous TBM resistant ( $\mathrm{HtF}, \mathrm{HtT}, \mathrm{HtP}, \mathrm{HtM})$ sunflower hybrids, as well as one TBM susceptible hybrid (Os) were used in the experiment (Table 1). All tested hybrids are a part of breeding program of Institute of Field and Vegetable Crops, Novi Sad, Serbia, and were chosen based on the differences in their genetic background (Jocić et al. 2008, 2011).

\section{Medium preparation}

MS medium (Murashige \& Skoog 1962) supplemented with different concentrations of herbicide Express 50SX (500 g TBM a.i. $\mathrm{kg}^{-1}$, DuPont, Denmark) $(2.0 \mu \mathrm{M}, 2.5 \mu \mathrm{M}$, $3.0 \mu \mathrm{M}, 3.5 \mu \mathrm{M}$ and $4.0 \mu \mathrm{M}$ ) and with $\mathrm{pH}$ either 7 or 8 was used for resistance testing. Filter sterilized herbicide solution was prepared as described by Dimitrijević et al. (2012) and added into the medium after autoclaving. Media with appropriate $\mathrm{pH}$ with no herbicide added were used as control.

\section{In vitro resistance testing}

Seed sterilization was performed according to TaškiAjduković \& Vasić (2005). Sterilized seeds were placed in Petri dishes with filter paper soaked in sterile water and germinated for 2 days as described by Dimitrijević et al. (2012). After 2 days, healthy sunflower seedlings, approximately $1.5 \mathrm{~cm}$ long, were placed on MS medium supplemented with different concentrations of herbicide and the control. Three seedlings were placed in each 250-ml Erlenmeyer flask. Every treatment was set in 4 repetitions. The seedlings were kept in a growth chamber at $25^{\circ} \mathrm{C}$ and a photoperiod $16 \mathrm{~h}$ day and $8 \mathrm{~h}$ night.

Development of above-ground part and roots of the seedlings on MS medium was observed for 12 days. On the 12th day of culture, root mass (RM) and aboveground part (AGM) were measured.

Table 1. Sunflower hybrids used for testing

\begin{tabular}{|c|c|c|}
\hline Name & SU resistance & Genotype \\
\hline $\mathrm{HoF}$ & resistant & Abasl1-2/Ahasl1-2* \\
\hline HoT & resistant & Abasl1-2/ Abasl1-2 \\
\hline HoP & resistant & Abasl1-2/ Ahasl1-2 \\
\hline HoM & resistant & Abasl1-2/ Abasl1-2 \\
\hline $\mathrm{HtF}$ & resistant & Ahasl1-2/abasl1 \\
\hline $\mathrm{HtT}$ & resistant & Ahasl1-2/ ahasl1 \\
\hline $\mathrm{HtP}$ & resistant & Abasl1-2/abasl1 \\
\hline $\mathrm{HtM}$ & resistant & Abasl1-2/ abasl1 \\
\hline Os & susceptible & abasl1/abasl1 \\
\hline
\end{tabular}

$*_{\text {nomenclature proposed by Sala et al. (2008) }}$

\section{Data analysis}

The experiment was set as a completely random design in 4 repetitions. The obtained data were analysed by ANOVA. The means were separated by least significant difference (LSD) test (STATISTICA 10), while the difference between particular treatments was established by use of Student's t-test of treatment mean differences.

\section{Results and Discussion}

Seedlings of all tested genotypes continued to develop after transfer onto herbicide supplemented media. After 3 days of culture, root development in susceptible genotype was halted in all treatments. In some plants, mostly grown at $\mathrm{pH} 8$, root necrosis was observed (Figures 1 and 2). The negative effect of TBM on root development has also been observed in 
Papaver rhoeas L. (Cirujeda et al. 2001), while in sunflower, imazapyr treatment led to significant reduction in aerial and radicular growth and root tip necrosis (Breccia et al. 2011). Roots of the homozygous resistant plants were branched, whereas roots of the heterozygous resistant plants had a well-developed primary root, which was elongated, and poorly developed lateral roots. That was especially visible at $\mathrm{pH} 8$ when higher herbicide concentrations were used (Figures 1 and 2). In contrast to the treated genotypes, root system of heterozygous genotypes was well developed in the control. There were no visible difference between root system development between non-treated homozygous resistant genotypes at $\mathrm{pH} 7$ and $\mathrm{pH} 8$.

ANOVA showed that there was statistically significant decrease of AGM of all treated susceptible plants compared to the control at both $\mathrm{pH}$ values (Figures 3 and 4). This is in agreement with the results of Vega et al. (2009) and Breccia et al. (2011) who also observed reduction of above-ground part of susceptible sunflower plants treated with herbicide (imazapyr). Herbicide treatments at $\mathrm{pH} 7$ led to decrease in AGM in all heterozygous genotypes, although this decrease was statistically significant only at herbicide concentrations of $3.5 \mu \mathrm{M}$ and $4.0 \mu \mathrm{M}$ (Figure 3). Herbicide treatment at $\mathrm{pH} 7$ had either none or positive effect on AGM in all homozygous genotypes. The only exception was HoP at $2.5 \mu \mathrm{M}$, where significant decrease of AGM compared to the control was observed (Figure 3). Generally, herbicide treatments at $\mathrm{pH} 8$ led to the decrease of AGM in all heterozygous genotypes. This decrease was significant in $3.0 \mu \mathrm{M}, 3.5$ $\mu \mathrm{M}$ and $4.0 \mu \mathrm{M}$ treatments (Figure 4). Herbicide treatment had no effect on 3 homozygous resistant genotypes (HoF, HoP and HoM), however it had a negative effect on HoT at $4.0 \mu \mathrm{M}$, where a decrease of AGM was observed (Figure 4).
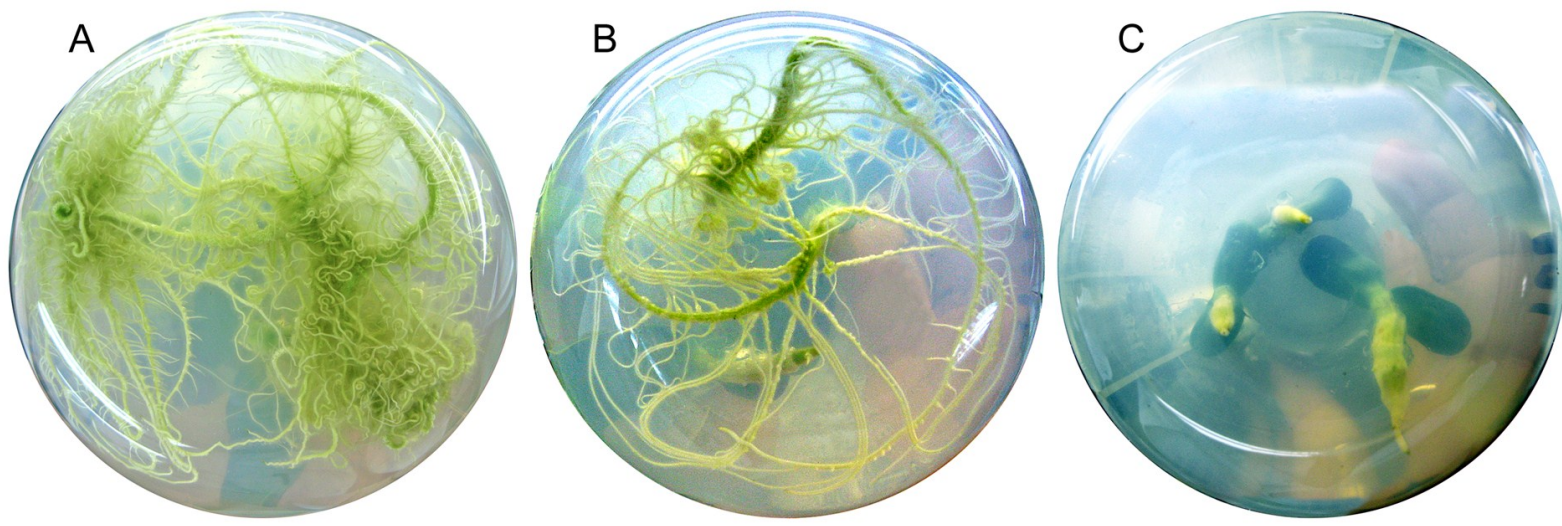

Figure 1. Root morphology of plants treated with $3.5 \mu \mathrm{M}$ Express 50SX (active ingredient tribenuron-methyl) at $\mathrm{pH} 7$ : a) homozygous resistant plants; b) heterozygous resistant plants; c) susceptible plants
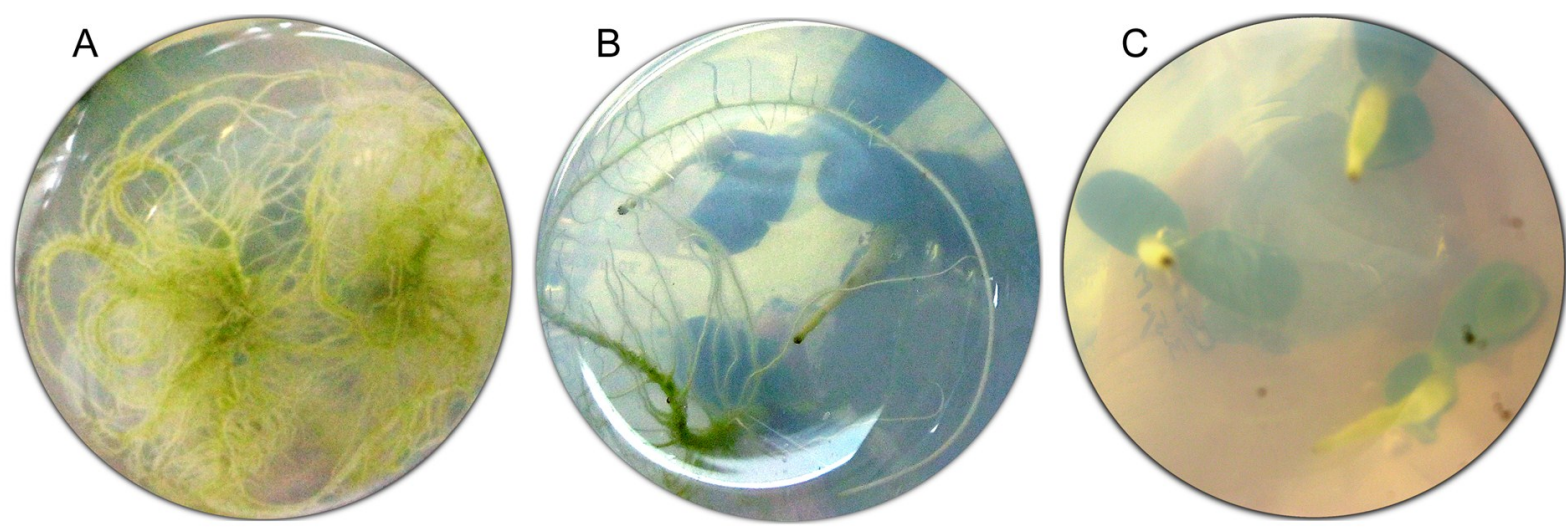

Figure 2. Root morphology of plants treated with $3.5 \mu \mathrm{M}$ Express 50SX (active ingredient tribenuron-methyl) at $\mathrm{pH} 8$ : a) homozygous resistant plants; b) heterozygous resistant plants; c) susceptible plants 


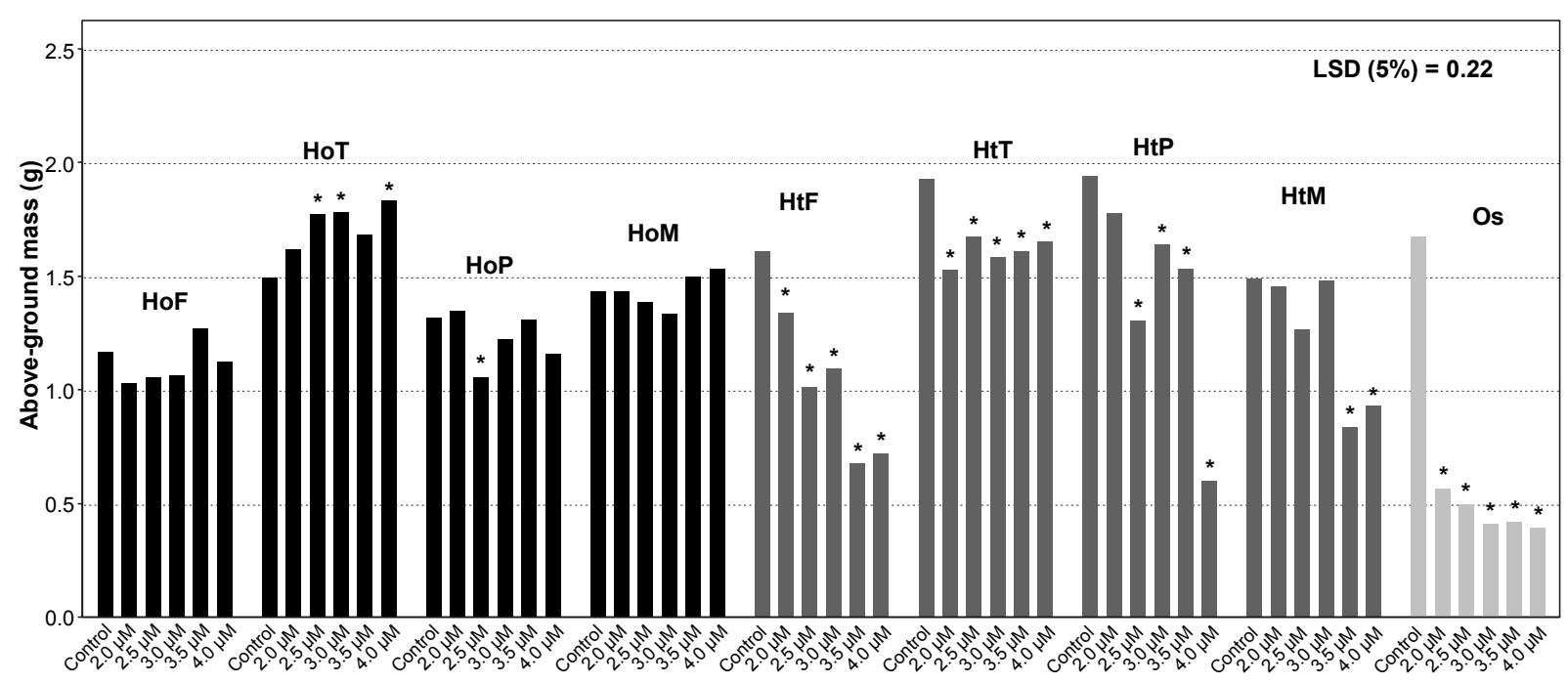

Herbicide treatment

Figure 3. Effect of tribenuron-methyl treatment on fresh above ground mass of tribenuron-methyl resistant and susceptible sunflower genotypes at $\mathrm{pH} 7$

*significant difference at $\alpha_{0.05}$ (values marked with asterisk differ significantly from control at $\alpha_{0.05}$ )

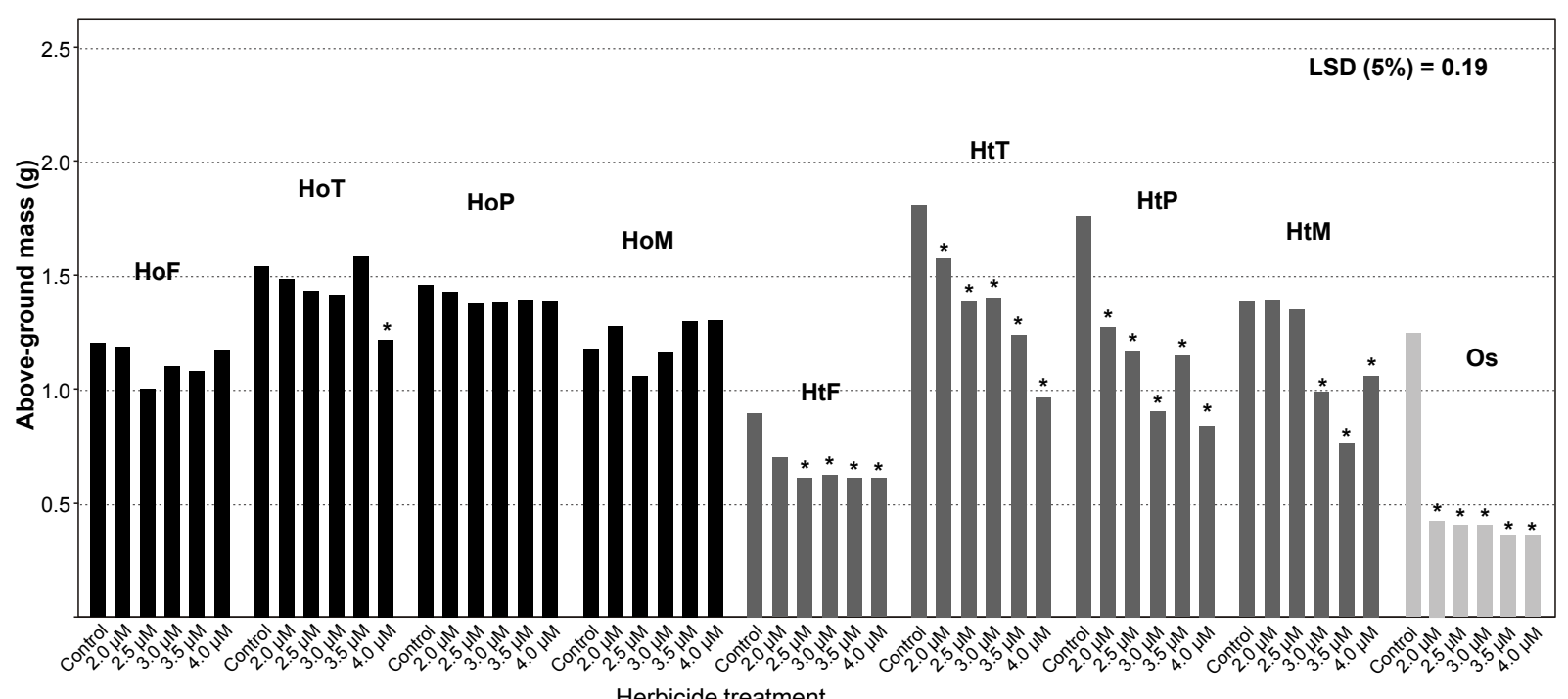

Herbicide treatment

Figure 4. Effect of tribenuron-methyl treatment on fresh above ground mass of tribenuron-methyl resistant and susceptible sunflower genotypes at $\mathrm{pH} 8$

*significant difference at $\alpha_{0.05}$ (values marked with asterisk differ significantly from control at $\alpha_{0.05}$ )

ANOVA analysis of RM of susceptible genotype showed significant reduction in all treatments compared to the control at both $\mathrm{pH}$ values (Figures 5 and 6). Generally, herbicide treatment led to the decrease of $\mathrm{RM}$ of all treated heterozygous genotypes compared to the control, even though this decrease was not statistically significant in all treatments (Figure 5). At pH 7, significant decrease of RM in all heterozygous genotypes was observed in $3.0 \mu \mathrm{M}, 3.5 \mu \mathrm{M}$ and $4.0 \mu \mathrm{M}$ treatments. RM of all homozygous genotypes tested was not affected by herbicide treatment. At $\mathrm{pH} 8$, herbicide treatment led to decrease of RM in all tested heterozygous resistant genotypes, except for genotype $\mathrm{HtP}$ at $2.0 \mu \mathrm{M}$. Herbicide treatment had no effect on $\mathrm{RM}$ in all homozygous resistant genotypes tested, except in $4 \mu \mathrm{M}$ treatment where negative effect of the treatment on HoF was observed (Figure 6). In addition, for better observation of the effect of herbicide treatment on $\mathrm{RM}$ growth, for $\mathrm{pH} 8$, results are displayed in two different ways. In Figure 6A, the emphasis is on the comparison of the effect of treatments within tested genotypes; while in Figure 6B the emphasis is on the comparison of treatments among different genotypes. What is shown in Figure 6B is the trend of decrease in 
overall RM with the increase of the herbicide concentration in different treatments. The decrease in $\mathrm{RM}$ is statistically significant between the control and all herbicide treatments, while the decrease of RM between treatments is statistically significant between $2.0 \mu \mathrm{M}$ and $4.0 \mu \mathrm{M}$ treatments and $2.5 \mu \mathrm{M}$ and $4.0 \mu \mathrm{M}$ treatments (Table 2).

In most cases root morphology differed between homozygous and heterozygous resistant genotypes. Similar effect of AHAS inhibitors on sunflower root development was observed in sunflower plants treated with IMI herbicides, where development of lateral roots was reduced in imazapyr-resistant intermediate sunflower genotype (Imr Imrimrimr $r_{2}$ ) at higher herbicide concentrations $(10 \mu \mathrm{M})$ in solid culture (Vega et al. 2009). Furthermore, sulfonylureas have proven to be a potent root growth inhibitor as they lead to thickening of the cell wall and perturbations in the root cap (Fayez \& Kristen 1996). These authors observed a clear correlation between root length, proline content and the degree of cell injuries. Opposite to sulfonylureas that inhibit cell division, some other herbicides (e.g. norflurazon) have proven to affect green plant organs due to their mode of action (inhibition of carotenoid biosynthesis) (Chamovitz et al. 1990). In general, different types of stress can affect complex plant traits in diverse manners. Such is nitrogen deficiency that, depending on the genotype and species tested, affects more severely shoot growth (El Midaouir et al. 1999) or root morphology (Eghball et al. 1993). Therefore, when evaluating plant resistance toward stress, suitable parameter for resistance evaluation should be chosen bearing in mind the nature of the stress analysed. In addition, the heritability of the trait evaluated can affect the level of correspondence between results obtained in the controlled environments and field trials - the correspondence is higher when the heritability of the trait is higher (Comas et al. 2013). However, Watt et al. (2013) observed that results obtained from analysing root growth in controlled environments can correspond to vegetative, but not reproductive plant stages in Triticum aestivum $\mathrm{L}$. during crop improvement.

In our rapid resistance test, fresh mass parameters proved to be extremely useful for discrimination between homozygous and heterozygous resistant genotypes. AGM discriminated between homozygous and heterozygous resistant genotypes at higher herbicide concentrations - $3.5 \mu \mathrm{M}$ and $4 \mu \mathrm{M}$, at $\mathrm{pH}$ 7. At $\mathrm{pH} 8$, the same effect was observed at even lower herbicide concentration $(3.0 \mu \mathrm{M})$. This could be explained by higher stability of herbicide molecule at higher $\mathrm{pH}$ values (Janjić 2002). Castro et al. (2004) found that higher $\mathrm{pH}$ values did not affect sunflower biomass production, as was the case in our study with biomass production of homozygous resistant genotypes. Therefore, all reduction of biomass at $\mathrm{pH} 8$ was caused by herbicide treatment.

All tested herbicide concentrations were found to be suitable for discrimination of TBM susceptible genotypes, since the growth of tested susceptible genotype was halted after 3 days of culture on all TBM supplemented media.

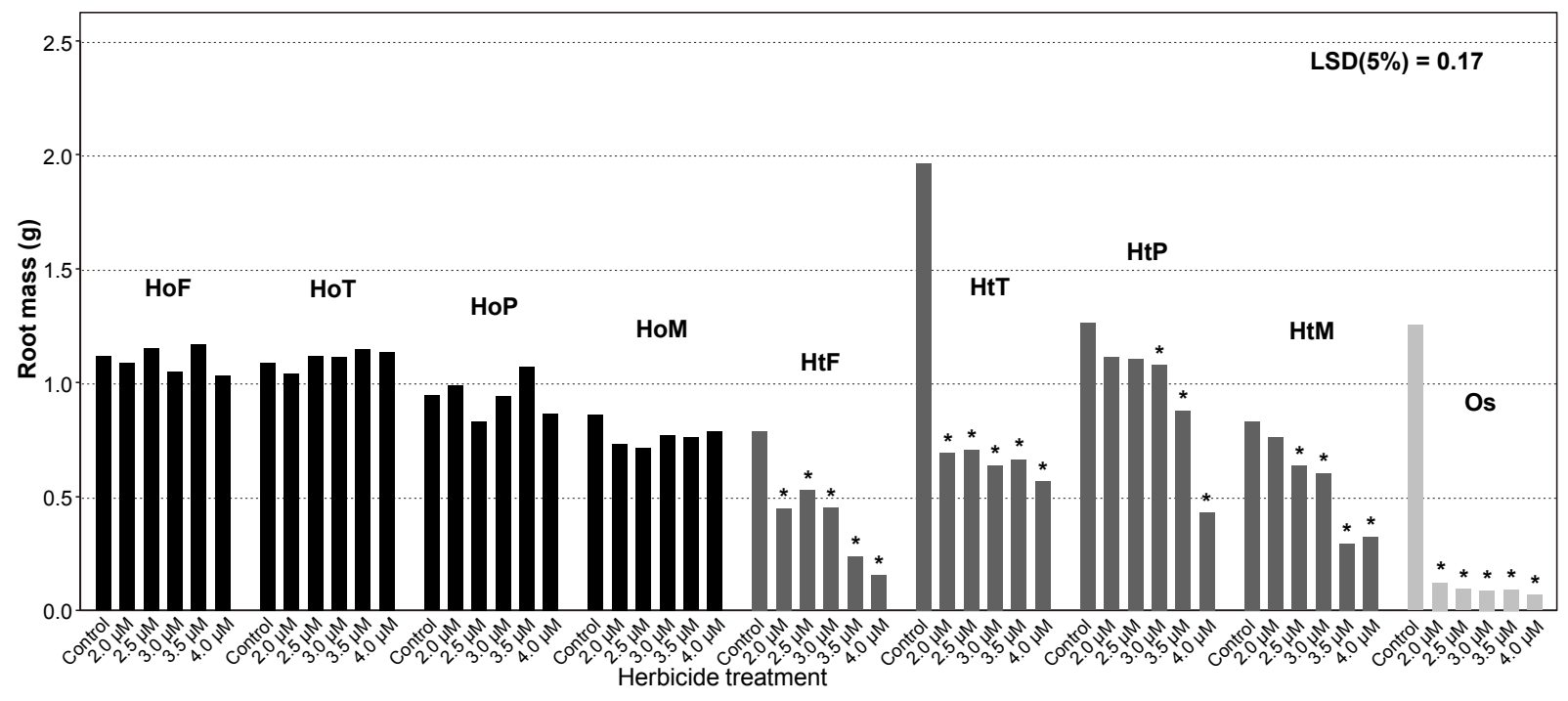

Figure 5. Effect of tribenuron-methyl treatment on fresh root mass of tribenuron-methyl resistant and susceptible sunflower genotypes at $\mathrm{pH} 7$

*significant difference at $\alpha_{0.05}$ (values marked with asterisk differ significantly from control at $\alpha_{0.05}$ ) 

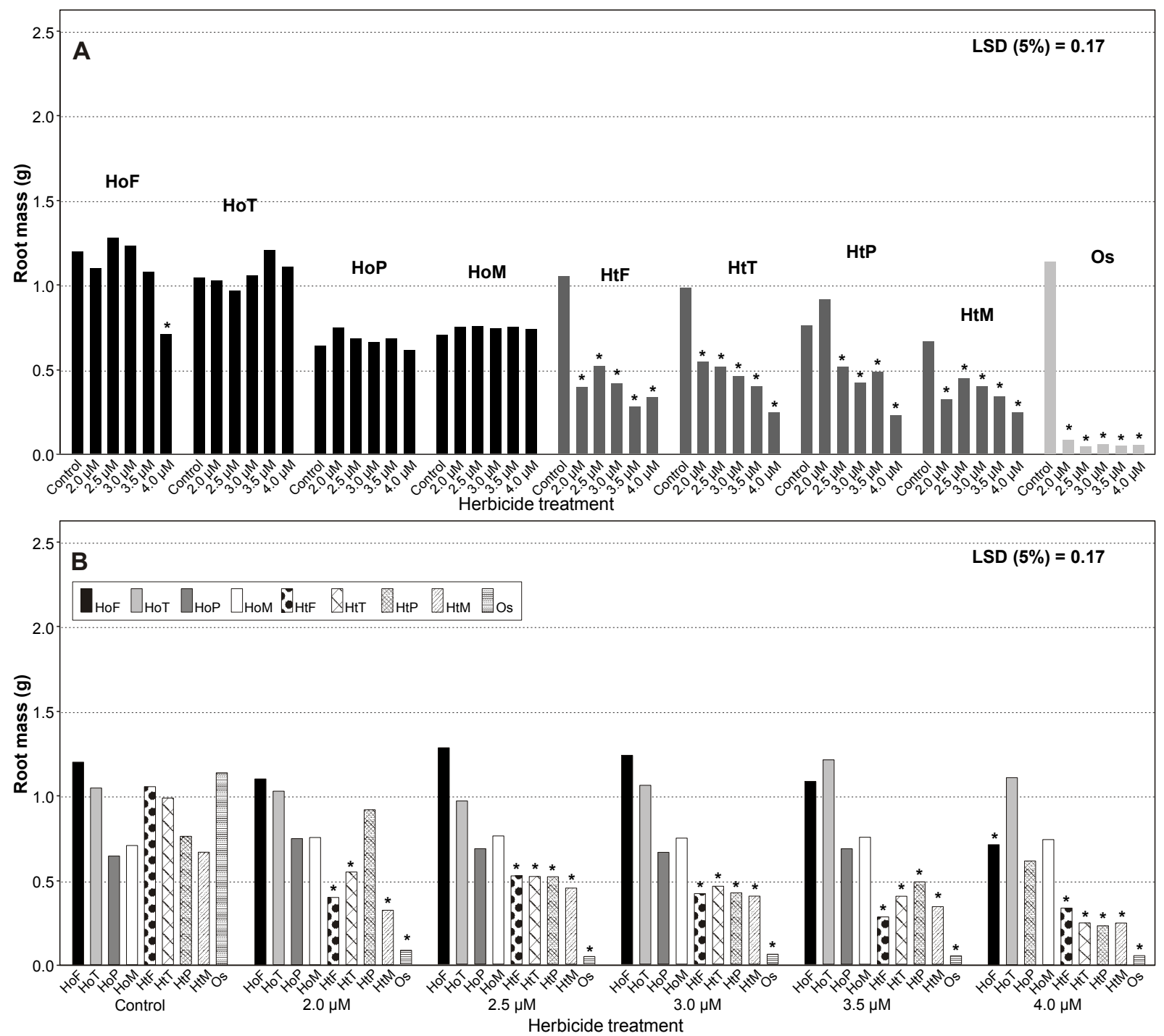

Figure 6. Effect of tribenuron-methyl treatment on fresh root mass of tribenuron-methyl resistant and susceptible sunflower genotypes at $\mathrm{pH}$ 8. A) Comparison of root mass by genotype; B) Comparison of root mass by herbicide treatment *significant difference at $\alpha_{0.05}$ (values marked with asterisk differ significantly from control at $\alpha_{0.05}$ )

By direct comparison of differences in AGM of a particular treatment, sometimes it can be difficult to discriminate between homozygous and heterozygous genotype (e.g. at $\mathrm{pH} 7,4.0 \mu \mathrm{M}$ treatment: HtT AGM was significantly decreased in comparison to the control, but the mean value of HtT AGM was higher than mean values of AGM of three homozygous resistant genotypes in the same treatment (Figure 3)). This is a consequence of differences in genetic background of the genotypes which affect plant fitness (Paris et al. 2008), as well as the fact that the genotypic factor is the sum of the heterozygotic gene effect (the additive effect of the allele/s present at the Ahasl1 locus) (Bulos et al. 2013).

Reduced growth in plants less tolerant to herbicides, after herbicide treatment, is considered to be a consequence of poor root growth and consequently decreased nutrient uptake (Soltani et al. 2008). When testing herbicide tolerance one must consider that both environmental factors and the genetic basis of the genotypes receiving the resistance genes have large influence on the expression of herbicide resistance (Jocić et al. 2011), especially bearing in mind that genetic background was found to influence the expressivities of some mutations in sunflower (Demurin et al. 2006). Considering a wide range in plant growth response to stress conditions in sunflower in respect to different genetic background (PereyraIrujo et al. 2008, Ahmad et al. 2009), we tested several genotypes in order to identify universal treatment for detection of TBM resistance. In addition, we used a nontreated control to properly observe and determine plant growth parameters between nonstressed and stressed conditions. 
Table 2. Decrease in overall root mass (g) between treatments at $\mathrm{pH} 8$

\begin{tabular}{lcccccc}
\hline Treatment & Control & $2.0 \mu \mathrm{M}$ & $2.5 \mu \mathrm{M}$ & $3.0 \mu \mathrm{M}$ & $3.5 \mu \mathrm{M}$ & $4.0 \mu \mathrm{M}$ \\
\hline Control & - & $0.254^{*}$ & $0.271^{*}$ & $0.302^{*}$ & $0.322^{*}$ & $0.433^{*}$ \\
$2.0 \mu \mathrm{M}$ & & - & 0.017 & 0.048 & 0.068 & $0.179^{*}$ \\
$2.5 \mu \mathrm{M}$ & & & - & 0.031 & 0.050 & $0.162^{*}$ \\
$3.0 \mu \mathrm{M}$ & & & - & 0.020 & 0.130 \\
$3.5 \mu \mathrm{M}$ & & & & - & 0.111 \\
$4.0 \mu \mathrm{M}$ & & & & & - \\
\hline
\end{tabular}

$*$ significant difference at $\mathrm{t}_{0.05}$ (values marked with asterisk present a significant decrease in root mass between treatments, $\mathrm{t}_{0.05(40)}=2,021$ )

The best $\mathrm{pH}$ and herbicide concentration combination for discrimination between homozygous and heterozygous resistant sunflower genotypes was 3 $\mu \mathrm{M}$ at $\mathrm{pH} 7$, while $\mathrm{RM}$ was found to be favourable parameter for discrimination between homozygous and heterozygous resistant genotypes. As in our work, RM was found to be a good resistance parameter by other authors, as well, and therefore widely used in herbicide resistance tests with different herbicides (Yim \& Bayer 1996, Torres et al. 2003).

\section{Conclusions}

In this study a new rapid laboratory test for detection of tribenuron-methyl resistant sunflower genotypes was developed. The test enables visual discrimination between resistant and susceptible genotypes in 5 days, as well as discrimination between homozygous and heterozygous resistant genotypes in 12 days. As it is not affected by the environment and could be used for screening of a large number of plants in a short period of time, the test could facilitate long breeding process during conversion of sunflower lines and hybrids into herbicide resistant form. Special advantage of this test is that it enables discrimination between homozygous resistant and heterozygous resistant sunflower genotypes, thus further accelerating and facilitating breeding for herbicide resistance.

\section{References}

Ahmad, S., Ahmad, R., Ashraf, M. Y., Ashraf, M., \& Waraich, E. A. (2009). Sunflower (Helianthus annuus L.) response to drought stress at germination and seedling growth stages. Pakistan Journal of Botany, 41: 647-654.

Al-Khatib, K., Baumgartner, J.R., \& Currie, R.S. (1999). Survey of common sunflower (Helianthus annuus) resistance to ALS inbibiting berbicides in northeast Kansas. 21st Sunflower Research Workshop, Fargo, ND, USA, Proceedings, 210-215.

Blamey, F.P.C., Zollinger, R.K., \& Schneiter, A.A. (1997). Sunflower production and culture. In: A.A. Schneiter (Ed.), Sunflower Technology and Production. American Society of Agronomy, Crop Science Society of America, Soil Science Society of America, Madison, WI, USA, 595-670.

Božić, D., Sarić, M., Malidža, G., Ritz, C., \& Vrbničanin, S. (2012). Resistance of sunflower hybrids to imazamox and tribenuronmethyl. Crop Protection, 39: 1-10.
Breccia, G., Vega, T., Nestares, G., Mayor, M.L., Zorzoli, R., \& Picardi, L. (2011). Rapid test for detection of imidazolinone resistance in sunflower (Helianthus annuus L.). Plant Breeding, 130: 109-113.

Bulos, M., Sala, C. A., Altieri, E., \& Ramos, M. L. (2013). Marker assisted selection for herbicide resistance in sunflower. Helia, 36: $1-16$.

Chamovitz, D., Pecker, I., Sandmann, G., Böger, P., \& Hirschberg, J. (1990). Cloning a gene coding for norflurazon resistance in cyanobacteria. Zeitschrift für Naturforschung C, 45: 482-486.

Chipman, D., Barak, Z., \& Schloss, J.V. (1998). Biosynthesis of 2aceto- 2 hydroxy acids: acetolactate synthases and acetohydroxyacid synthases. Biochimica Biophysica Acta, 1385: 401419.

Cirujeda, A., Recasens, J., \& Taberner, A. (2001). A qualitative quicktest for detection of herbicide resistance to tribenuron-methyl in Papaver rhoeas. Weed Research, 41: 523-534.

Comas, L. H., Becker, S. R., Von Mark, V. C., Byrne, P. F., \& Dierig, D. A. (2013). Root traits contributing to plant productivity under drought. Frontiers in Plant Science, 4.

Demurin, Y. N., Efimenko, S. G., \& Peretyagina, T. M. (2006). Expressivity of tocopherol mutations in sunflower. Helia, 29: 5562.

Dimitrijević, A., Imerovski, I., Miladinović, D., Jocić, S., Malidža, G., Šurlan-Momirović, G., \& Miklič, V. (2012). Laboratory method for detection of tribenuron-methyl resistant sunflower (Helianthus annuus L.). 18th International Sunflower Conference, Mar Del Plata and Balcarce, Argentina, Proceedings, 519-523.

Eghball, B., Settimi, J.R., Maranville, J.W., \& Parkhurst, A.M. (1993). Fractal analysis for morphological description of corn roots under nitrogen stress. Agronomy Journal, 85: 287-289.

El Midaouir, M., Talouizete. A., Bervillé, A., \& Benbellal, M. (1999). Response of sunflower (Helianthus annuus L.) to nitrogen and potassium deficiency. Helia, 22: 139-148.

Fayez, K.A., \& Kristen, U. (1996). The influence of herbicides on the growth and proline content of primary roots and on the ultrastructure of root caps. Environmental and Experimental Botany, 36: $71-81$.

Janjić, V. (2002). Sulfoniluree. Institut za istrazivanja u poljoprivredi "Srbija", Akademija nauka i umjetnosti Republike Srpske.

Jocić, S., Malidža, G., Cvejić, S., Hladni, N., Miklič, V., \& Škorić, D. (2011). Development of sunflower hybrids tolerant to tribenuron methyl. Genetika, 43: 175-182.

Jocić, S., Miklič, V., Malidža, G., Hladni, N., \& Gvozdenović, S. (2008). New sunflower bybrids tolerant of tribenuron-methyl. 17th International Sunflower Conference, Spain. Paris, Proceedings, 505-508.

Kondić-Špika, A., \& Jevtić, R. (2002). Tolerance of spring and winter wheats to herbicide in in vitro culture. Pesticides, 17: 125-129.

Kondić-Špika, A., Petrović, K., Jevtić, R., Kobiljski, B., \& Pucarević, M. (2009). Sulfonylurea tolerance of wheat genotypes in zygotic embryo culture. Archives of Biological Sciences, Belgrade, 61: 453-458.

LaRossa, R.A., \& Schloss, J.V. (1984). The sulfonylurea herbicide sulfo-meturon methyl is an extremely potent and selective inhibitor of aceto-lactate synthase in Salmonella typhimurium. Journal of Biology and Chemistry, 259: 8753-8757. 
Malidža, G., Jocić, S., Škorić, D., \& Orbović, B. (2004). Clearfield sunflower production system. Zbornik radova Instituta za ratarstvo $i$ povrtarstvo, 40: 279-290.

Menne, H., \& Kocher, H. (2007). HRAC classification of herbicides and resistance development. In: W. Kramer and U. Schirmer (Eds.), Modern Crops Protection Compounds, WILEY-VCH Verlag GmbH \& Co. KGaA, Weinheim, Germany, Vol. 3, 5-26.

Miller, J.F., \& Al-Khatib, K. (2004). Registration of 2 oilseed sunflower genetic stocks, SURES-1 and SURES-2, resistant to tribenuron herbicide. Crop Science, 44: 1037-1038.

Murashige, T., \& Skoog, F. (1962). A revised medium for rapid growth and bioassays with tobacco tissue culture. Plant Physiology, 15: 473-497.

Paris, M., Roux, F., Berard, A., \& Reboud, X. (2008). The effects of the genetic background on herbicide resistance fitness cost and its associated dominance in Arabidopsis thaliana. Heredity, 101: 499-506.

Pereyra-Irujo, G. A., Velázquez, L., Lechner, L., \& Aguirrezábal, L. A. (2008). Genetic variability for leaf growth rate and duration under water deficit in sunflower: analysis of responses at cell, organ, and plant level. Journal of Experimental Botany, 59: 22212232.

Sala, C.A., Bulos, M., Echarte, A.M., Whitt, S.R., \& Ascenzi, R. (2008). Molecular and biochemical characterization of an induced mutation conferring imidazolinone resistance in sunflower. Theoretical and Applied Genetics, 108: 105-112.

Saunders, J.W., Acquaah, G., Renner, K.A., \& Doley, W.P. (1992). Monogenic dominant sulfonylurea resistance in sugar beet from somatic cell selection. Crop Science, 32: 1357-1360.
Soltani, N., Gillard, C.L., Swanton, C.J., Shropshire, C., \& Sikkema, P.H. (2008). Response of white bean (Phaseolus vulgaris) to imazethapyr. Crop Protection, 27: 672-677.

Taški-Ajduković, K.J., \& Vasić, D.M. (2005). Different sterilization methods for overcoming internal bacterial infection in sunflower seeds. Proceedings for Natural Sciences of Matica Srpska Novi Sad, 109: 59-64.

Torres, A.C., Nascimento, W.M., Vasconcelos Paiva, S.A., \& de Aragao, F.A.S. (2003). Bioassay for detection of transgenic soybean seeds tolerant to glyphosate. Pesquisa Agropecularia Brasiliera, 38: 1053-1057.

Umbarger, H.E. (1978). Amino acid biosynthesis and its regulation. Annual Reviews of Biochemistry, 47: 533-606.

Vasić, D., Malidža, G., \& Škorić, D. (2002). The effect of herbicides on cultivated sunflower in field and in vitro conditions. Zbornik radova Instituta za ratarstvo i povrtarstvo, 37: 15-25.

Vega, T., Breccia, G., Nestares, G., Mayor, M.L., Zorzolia, R., \& Picardia, L. (2009). Soil-less bioassays for early screening for resistance to imazapyr in sunflower (Helianthus annuus L.). Pest Management Science, 65: 991-995.

Watt, M., Moosavi, S., Cunningham, S. C., Kirkegaard, J. A., Rebetzke, G. J., \& Richards, R. A. (2013). A rapid, controlledenvironment seedling root screen for wheat correlates well with rooting depths at vegetative, but not reproductive, stages at two field sites. Annals of Botany, 112: 447-455.

Yim, K., \& Bayer, D.E. (1996). Root growth inhibition of rice by bensulfuron. Weed Research, 35: 49-54.

\title{
Brzi test za ispitivanje otpornosti suncokreta na tribenuron metil
}

\author{
Aleksandra Dimitrijević · Ivana Imerovski · Dragana Miladinović · \\ Siniša Jocić · Sandra Cvejić · Goran Malidža · \\ Branislav Kovačević · Gordana Šurlan-Momirović
}

Sažetak: Razvijen je brzi laboratorijski test za detekciju genotipova suncokreta otpornih na tribenuron metil. Po četiri hibrida suncokreta homozigotno i heterozigotno otporna na tribenuron metil, kao i jedan neotporan hibrid su gajeni na MS podlozi sa $\mathrm{pH}$ vrednošću ili 7 ili 8 i sa različitim koncentracijama herbicida Express 50X, čija je aktivna materija tribenuron-metil $(2.0 \mu \mathrm{M}, 2.5 \mu \mathrm{M}, 3.0 \mu \mathrm{M}, 3.5 \mu \mathrm{M}$ i $4.0 \mu \mathrm{M})$. Ispitivan je uticaj pH i koncentracije herbicida $\mathrm{u}$ podlozi na masu nadzemnog dela i korena klijanaca testiranih hibrida. Vizuelne razlike između otpornih i neotpornog hibrida su uočene nakon 5 dana kulture, dok su se razlike između homozigotnih i heterozigotnih otpornih hibrida pojavile nakon 12 dana kulture. Sve testirane koncentracije herbicida i testirani morfološki parametri su se pokazali kao dobri za identifikaciju neotpornih genotipova. Najbolja kombinacija pH i koncentracije herbicida za razlikovanje homozigotnih od heterozigotnih otpornih genotipova je bila $3.0 \mu \mathrm{M}$ na pH 7, a morfološki parametar masa korena.

Ključne reči: biološka proba, Helianthus annuus L., herbicidi, selekcija, sulfoniluree, tolerantnost 